\title{
A KÖZÖSSÉG ÁLTAL TÁMOGATOTT MEZÖGAZDÁLKODÁS SZUBJEKTÍV ASPEKTUSAI
}

\section{BIRTALAN ILONA LILIÁNA ${ }^{1,2,3}$ - KIS BERNADETT ${ }^{4}$ - BÁRDOS GYÖRGY ${ }^{3}$}

\author{
${ }^{1}$ Eötvös Loránd Tudományegyetem, Pszichológiai Doktori Iskola \\ ${ }^{2}$ Eötvös Loránd Tudományegyetem, Pszichológiai Intézet \\ ${ }^{3}$ Eötvös Loránd Tudományegyetem, Egészségfejlesztési és Sporttudományi Intézet \\ ${ }^{4}$ Szegedi Tudományegyetem, Juhász Gyula Pedagógusképző Kar, \\ Alkalmazott Egészségtudományi és Egészségfejlesztési Intézet \\ E-mail: birtalan.liliana@ppk.elte.hu \\ Beérkezett: 2019. február 22. - Elfogadva: 2019. október 8.
}

Elméleti háttér: A közösség által támogatott mezôgazdálkodás (CSA) gyorsan növekvố jelenség világszerte, a helyi élelmiszer termelésének és elosztásának az a módja, amikor a termeló és a fogyasztók (tagok) közvetlenül elkötelezôdnek egymás felé. A közösségi mezôgazdálkodási rendszerek, mint alulról jövô társadalmi kezdeményezések, az élelmiszerek „árutlanitása” felé tett törekvésként is értelmezhetók, és szorosan kapcsolódnak a fenntarthatóság kérdésköréhez, mely a pszichológiai és az egészségfejlesztési diskurzusba hazánkban még alig került be.

Módszertan: A szakirodalmak kiválasztása során elöször konkrét szókombinációk mentén kerestünk cikkeket, majd a talált cikkek irodalmi hivatkozásait áttanulmányoztuk; illetve szakirodalom-keresô portálok elsôdlegesen talált cikkeihez ajánlott további cikkeit tekintettük át a CSA-részvétellel járó tapasztalatok szempontjából.

Eredmények: Áttekintésünk alapján látható, hogy a részvétel nemcsak konkrét elönyök mentén értelmezhetố, hanem a további aspektusok, mint Hasonló gondolkodás, Lokalitás (város-vidék tengely), Személyes törơdés, Életmódváltás, valamint az Újraírt sémák taglalása is legalább olyan fontos.

Következtetések: Véleményünk szerint a CSA-ban való részvétel átgondolása hasznos információkat nyújthat többek között a fenntartható pozitív mentális egészség fogalmának kibontásában.

Kulcsszavak: közösség által támogatott mezôgazdálkodás; CSA-részvétel (tagság); fogyasztás; életmód; mentális egészség 


\section{BEVEZETÉS}

Fogyasztásunk mögött igényeink, szükségleteink állnak. Azok kielégítésére törekszünk, amikor fogyasztunk, ugyanakkor minden ember minden döntési szituációban egyedileg viselkedik, amit befolyásolnak kulturális és társadalmi tényezôk, személyes és pszichológiai jellemzók (Kotler, 2004). Jean Baudrillard elméletét feldolgozva Gulyás $(2011,25)$ a következóket írja: „a jelenlegi fogyasztói társadalom a tömegtermelés következményeként alakult ki, és radikális elidegenedés jellemzi. Azt állítja [Baudrillard], hogy az áruszemlélet olyannyira általánosult, hogy már nemcsak a termelési és a munkafolyamatokat vezérli, hanem az egész kultúrát, a szexuális és az emberi kapcsolatokat, de még az emberek vágyait is.”

Számos olyan fogyasztói csoportosulás létezik ma már, amely megkérdôjelezi a fogyasztói társadalom keretrendszerét, különösen az iparosodott agrártermelést. Ezek egyike a közösség által támogatott mezőgazdálkodás ${ }^{1}$ (angol nevén Community Supported Agriculture, rövidítve: CSA), amely ugyan nem kritizálja közvetlenül a fogyasztói társadalom múködését, mégis igyekszik minimalizálni az uralkodó mezôgazdasági módszerek negatív hatásait (Thompson és Coskuner-Balli, 2007). Az elsô CSA-k megjelenése óta már körülbelül hatvan év telt el (Tegtmeier és Duffy, 2005), az ezzel kapcsolatos kutatások is már jó 50 éve folynak. Úgy túnik, hogy a jelenség tudományos vizsgálata mindig aktuális, miközben a kutatók egyre újabb megközelítéseket alkalmaznak vizsgálataik során.

Alulról jövô társadalmi kezdeményezésekként a CSA-k szorosan kapcsolódnak a fenntarthatóság kérdésköréhez (Cohen, Gearhart és Garland, 2012), mely a pszichológiai és az egészségfejlesztési diskurzusba még alig került be hazánkban (Kis, 2017). A fenntartható fejlôdés fogalma egy olyan fejlődést jelent, mely során a jelen generációk szükségletei kielégülnek, de úgy, hogy ezzel a jövô generációknak ne csökkenjen az esélye, és az ô szükségleteik is kielégülhessenek (Brundtland, 1987). A koncepció vonatkozik a gazdaságra, a társadalomra és a környezetre egyaránt. A CSA-k a maguk nem növekedési (small is beautiful) gazdasági szemléletével, egyenlôséget, részvételi demokráciát és etikus bánásmódot propagáló társadalmi szemléletükkel, és jellemzôen az ökológiai gazdálkodás szempontjainak figyelembevételével a fenntarthatósági gondolatot képviselik. Vagyis a CSA-rendszerek jók a helyi gazdaságnak, az embereknek és a földnek, természetnek egyaránt (Kis, 2014). Sajnálatos módon a fenntarthatóság témája kevéssé reprezentált mind a pszichológia, mind az egészségfejlesztés területén, pedig úgy tûnik, hogy a CSA-k lehetôséget biztosítanak a fenntartható viselkedésre, amely pedig a pozitív mentális egészséggel mutat kapcsolatot (ld. Birtalan, Rigó, Bárdos, Rácz és Oláh, 2018; Fajzi és Erdei, 2015; Kis, 2017).

Ahogy látni fogjuk, a részvételnek számos fontos, egymással is összefüggô megközelítése lehet, amelyek megismerése nélkül nehezen érthetô az a sajátos magatartási mintázat, ami a közösségi mezógazdálkodáshoz tartozó tagságot jellemzi. A CSA-ban

A magyar és angol fogalmak máshogyan használatosak: míg a CSA-ba csak a mezôgazdasági termelés és elosztási rendszerben múködô zöldségközösségek tartoznak, a közösség által támogatott mezôgazdálkodást rövidítô, hazánkban használatos „közösségi mezôgazdálkodás” kifejezésbe a közösségi kertek is beleérthetôk (Réthy és Dezsény, 2013). A fogalmat ezért most az angol betûszóval jelezzük a cikk során. 
való részvétel során termelôk és tagok közvetlen kapcsolódása egyértelmúen egészséges táplálkozási potenciált biztosít a tagság számára, miközben az ezzel járó vállalások komoly elköteleződéssel járnak (Allen, Rossi, Woods és Davis, 2017; Cohen és mtsai, 2012; Landis és mtsai, 2010; Minaker és mtsai, 2014). Szakirodalmi áttekintésünk során célunk az volt, hogy azonosítsuk, értékeljük és szintetizáljuk a CSA-részvételt vizsgáló szakirodalmakat a részvétellel járó tapasztalatok, a résztvevôkben kialakuló szubjektív kép szempontjából. Véleményünk szerint a közösségi mezőgazdálkodásban való részvétel átgondolása emellett hozzájárulhat a fenntartható pozitív mentális egészség (Fajzi és Erdei, 2015) fogalmának kibontásához is.

\section{CSA ÉS RÉSZVÉTEL}

A hazai mindennapi szóhasználatban gyakran zöldségközösség néven is emlegetett, közösség által támogatott mezógazdálkodás a tudatos fogyasztásra törekvô mozgalmak egyik gazdaságilag legjobban leírható fajtája (Landis és mtsai, 2010). A CSA-knak nincs jól bevett, konkrét definíciója (Charles, 2011), de a jelenleg is múködô közösségek alapelve, hogy a központi szerepben megjelenô termelô közvetlenül és rendszeresen látja el fogyasztóit (pontosabban a tagokat) friss és jellemzően biominôségú terményekkel (Lang, 2005). A közvetlen szerzódéses kapcsolat közöttük egy szezonra jön létre, körülbelül 40-50 hétig tartó idôszakra, amely évente hosszabbítható.

CSA-k tagjai fôleg a környezettudatos, az organikus élelmiszerek fogyasztását előnyben részesítô városlakók. A nem és társadalmi státusz szintén befolyásolja a részvételt: a CSA-k irányába leginkább a magasan képzett nôk lépnek, akik anyagilag biztos háttérrel rendelkeznek (Goland, 2002; Jarosz, 2011; Zepeda és Li, 2006).

A részvétel kézzelfogható elônye a tagok számára, hogy élelmiszer-biztonságot garantál, magas tápanyagtartalmú és biológiailag tiszta élelmiszert nyújt, valamint tájékozottságot biztosít az élelmiszer származásával kapcsolatban (Forbes és Harmon, 2008). Mivel minden egyes CSA alkalmazkodik a helyi viszonyokhoz, vagyis igyekszik egyensúlyban múködni a szélesebben értelmezett gazdasági, társadalmi és környezeti viszonyok között, sokféle változata jöhet létre a logisztika formája, a tagi önkéntes lehetôségek, az árazás vagy akár a közösségi múködés tekintetében. Ugyanakkor bizonyos múködési részletek, mint a szezonalitás elve a termelésben, a rendszeres áruátvétel és a közvetlen kapcsolat a termelôvel mindenhol megjelennek.

Fontos megjegyezni, hogy az elsô közösségi mezôgazdálkodási formák céljai között az aktív közösségben múködés kiemelt helyen szerepelt (DeLind, 2011; DeLind és Ferguson, 1999; Press és Arnould, 2011). Napjainkban a CSA megjelenési formái széles skálán mozognak: a teljes mértékben közösségileg múködtetett gazdaságoktól egészen olyan piacorientált szervezôdésekig is találunk példákat, ahol a közösségi tényezônek csak minimális szerepe van (Adam, 2006; Cone és Kakaliouras, 1995; Goland, 2002). Egyes szerzốk szerint sokkal inkább instrumentális gazdasági kapcsolódás formájában múködnek ma a CSA-k (Pole és Gray, 2013), ami jelentheti azt is, hogy a fogyasztók épp csak átveszik a csomagot, és minimális kommunikáció zajlik köztük. Emögött általános társadalmi tendenciákat feltételeznek a kutatók (ld. Putman megközelítése in 
Pole és Gray, 2013), de az egészséges élelmiszerek fogyasztásának fokozódó igénye is hatással lehet erre (Lang, 2010).

A CSA-részvételükkel azok inkább elégedettek, akik fizikailag részt vesznek a gazdaság tevékenységében, idősebbek, és a zöldségek fogyasztása felé elkötelezettek (Lang, 2005). A minóségi saját élelmiszer beszerzése, amit aztán meg lehet osztani a személyes környezetben, és a helyben termelés miatti szállítás révén vélt kevesebb energia felhasználása az egészség- és környezettudatos fogyasztás élményét nyújtja a tagoknak (Chen, 2013; Hayden és Buck, 2012). Nem mellesleg, e csatornán keresztül a kapott bioélelmiszert sokszor olcsóbban érik el a tagok a kiskereskedelmi árhoz viszonyítva, tekintettel arra, hogy a viszonteladók kimaradnak az elosztási láncból (Cooley és Lass, 1998; Sabih és Baker, 1998).

A részvétel előnyei mellett általában kevés szó esik a csatlakozáskor arról, hogy a tagság a mindennapi életvitel szempontjából számos nehézséget is rejt, ami magas kilépési arányt eredményez, és ez éves szinten akár 50\%-os tagcserét is jelenthet (Goland, 2002). Az elkötelezôdôk a gazda számára méltányos megélhetést biztosító havi átalányt fizetnek, a várható termények fajtáját és mennyiségét a szezon elootti éves vetéstervezés hivatott biztosítani (Kis, 2014). A CSA-részvétel számtalan esetben tehát kész helyzet elé állítja a tagot: például a várható termények fajtáját és mennyiségét kevéssé tudják szabályozni. A szélsôséges idôjárás miatti ínségesebb idôszakok megoldása (tehát fix általányért kapott kevesebb termény), vagy bôséges idôszak esetén az otthoni tárolás és feldolgozás kényszere (tehát egy hét múlva jön az újabb terménycsomag) okozta folyamatos terhelés szintén komoly kihívást jelenthet a tagok számára. Ezen túl az ökológiai gazdálkodás következtében elôkerüloo, eddig ismeretlen zöldségek, vagy a szokatlan elôkészítési folyamatok (pl. föld és/vagy éloolények eltávolítása a terményrôl, más, kevésbé ismert fúszerek, például izsóp használata) próbára teszik a tagokat (Tegtmeier és Duffy, 2005). A CSA-részvétel jellemzôinek összefoglalóját, mely a fogyasztó szándékát jelentôsen befolyásoló pszichológiai szempontokat is felsorakoztatja, az 1. táblázatban szemléltetjük.

Fontos megjegyezni, hogy az általánosabb gazdasági elemzéseken túl (pl. kiskereskedelmi érték, árazási modell elemzések), például a vásárlói húség, vásárlói elégedettség, érzékelt termék-érték is gazdasági elemzések tárgya a CSA-khoz kapcsolódóan (Chen, 2013; Cronin, Brady és Hult, 2000; Lang, 2005; Zepeda és Li, 2006). A terme-

1.táblázat. CSA-részvétel jellemzói

\begin{tabular}{|c|c|c|c|}
\hline Múkööési elvek & Részvétel előnyei & Részvétel nehézségei & $\begin{array}{l}\text { Pszichológiai } \\
\text { szempontok }\end{array}$ \\
\hline $\begin{array}{l}\text { termelőtől kapott } \\
\text { termény } \\
\text { ökológiai gazdálkodás } \\
\text { gazda méltányos meg- } \\
\text { élhetése } \\
\text { elkötelezôdés a ter- } \\
\text { melö-tagok között } \\
\text { közösségi müködési } \\
\text { forma }\end{array}$ & $\begin{array}{l}\text { bioélelmiszer } \\
\text { élelmiszer-biztonság } \\
\text { tájékozottság az élel- } \\
\text { miszer forrásáról } \\
\text { egészséges táplálkozás } \\
\text { kapcsolódás mások- } \\
\text { hoz }\end{array}$ & $\begin{array}{l}\text { ismeretlen termények } \\
\text { otthoni tárolás } \\
\text { feldolgozás kényszere } \\
\text { logisztika } \\
\text { egyeztetési nehézsé- } \\
\text { gek/konfliktusok }\end{array}$ & $\begin{array}{l}\text { egészségtudatosság } \\
\text { környezettudatosság } \\
\text { természetközeliség } \\
\text { bizalom } \\
\text { pszichológiai nehéz- } \\
\text { ségek (pl. új szokások } \\
\text { kialakítása, alkalmaz- } \\
\text { kodás a természethez, } \\
\text { lemondás a kénye- } \\
\text { lemrôl) }\end{array}$ \\
\hline
\end{tabular}


lôktôl a tagoknak juttatott többletértékek (pl. tudás, élelmiszer-biztonság, személyes odafigyelés) megértése, az emberi közelség, a bizalom, mint e fogyasztási térben létrejövố közjavak taglalása további, már alternatívabb utakat bejáró gazdasági elemzéseket jelentenek a CSA múködési keretének megértésében (Trauger, Sachs, Barbercheck, Brasier és Kiernan, 2010). A számszerúsíthetô, gazdaságilag kézzelfogható elônyök mellett a részvételnek számos további hozadéka is van (Kloppenburg, Hendrickson és Stevenson, 1996), amelynek feltérképezésére jelen tanulmány törekedett a szakirodalmi áttekintés során.

\section{A CSA-RÉSZVÉTELLEL JÁRÓ TAPASZTALATOK AZONOSÍTÁSA}

A szakirodalmak kiválasztása során (2016. november - 2017. május között) elôször konkrét szókombinációk mentén kerestünk cikkeket, az invariáns kifejezésünk mindig a CSA volt, és ezt követte az alábbi szavak egyike: szakirodalmi áttekintés, kvalitatív (módszertan), motiváció, érték, részvétel, tagság, fogyasztó, fogyasztás, hozzáállás, egészség, pszichológia, egészségpszichológia. Az elsôdleges keresést követôen a talált cikkek irodalmi hivatkozásait is áttekintettük, illetve szakirodalom-keresô portálok (pl. Google Scholar; Science Direct) először talált cikkeihez ajánlott további cikkeit tekintettük át. Az áttekintésbe azok az anyagok kerültek be (kb. 100 cikk), amelyek az egyéni tagi-részvételi tapasztalatok feldolgozását tekintve tartalmaztak releváns információkat.

A fellelhetô aktuális, releváns szakirodalom feldolgozása során értelmeztük és rendszereztük azok mondanivalóit a részvétellel járó tapasztalatok szempontjából. A különbözô nézôpontokat (pl. közegészségügy, vidékszociológia, antropológia; kvalitatív vagy kvantitatív, kevert módszertani vizsgálatok; gazdára fókuszáló vagy résztvevôi vizsgálatok) integráltuk, és törekedtünk következtetéseket levonni, átfogóan felvázolni a vizsgált idôszakban elérhetô CSA-elemzéseket. A CSA-tagság hátterének megértéséhez elengedhetetlen a tág megközelítésrendszer, amely meglátásunk szerint több elembôl áll, ilyenek: a Hasonló gondolkodás, a Lokalitás (város-vidék tengely), a Személyes törôdés, az Egészséges táplálkozás, az Életmódváltás és az Újraírt sémák.

\section{Hasonló gondolkodás}

A CSA-k mint alulról jövô társadalmi kezdeményezések, a környezettudatos és társadalmilag aktív termelôk és fogyasztók környezetében alakulnak ki (Cone és Myhre, 2000; Jarosz, 2008; Lamb, 1994; Landis és mtsai, 2010). A hasonló gondolkodás, a hasonló elveket fontosnak tartó közeg értéket képvisel a tagok számára - derül ki egy 565 fôs amerikai vizsgálatból (Pole és Gray, 2013), és a CSA sokféle szemléletmód alá (ld. alább) sorolható be.

A CSA-k népszerúsége pl. az USA-ban azon az egyszerú tényen is alapul, hogy a „helyi élelmiszer” mozgalom (,local food”) részeként is értelmezhetôk, a helyi élelmiszerek közvetlen beszerzési forrásaként (DeLind, 2011; Zepeda és Leviten-Reid, 2004; Zepeda és Li, 2006). A helyi termelés és fogyasztás elhelyezhetô továbbá a food miles (terme- 
lési, illetve fogyasztási helyek közötti távolság minimalizálása elsôsorban az eljuttatás energiaigényére koncentrálva), vagyis a hazánkban leginkább 50 kilométeres diéta néven futó környezettudatos szemléletmód megvalósulásaként, mivel jellemzôen a gazdaság és az átvételi pontok közel esnek egymáshoz (Zsolnai és Podmaniczky, 2010). A CSA egy másik társadalmi kezdeményezés alá is sorolható, ez a voluntary simplicity, azaz az önkéntes egyszerúség, amelynek lényege a fogyasztás és az anyagi javak keresésének önkéntes, tudatos és szándékos csökkentése (Thompson és Coskuner-Balli, 2007).

A CSA-kban való tagságnak lehet erôs kiútkeresố alapja is (counter-hegemony), tudniillik a hagyományos termeléssel szembeni aggódás, vagy a tudatos és fenntartható fogyasztás melletti elkötelezôdés is szerepet játszhat a részvételben (Cox és mtsai, 2008; Press és Arnould, 2011; Ravenscroft, Moore, Welch és Hanney, 2013). Mint az alternatív élelmiszer-hálózatok egy formája, jellemzóen az élelmiszerhez való hozzáférés (accessibility to food), a közelség (proximity) koncepcióival is társítják (Pascucci és mtsai, 2016). Globális szemszögból nézve számottevô különbségek vannak a különbözô kultúrák motivációi szempontjából: míg Észak-Amerikában a CSA-k köré azok a fogyasztók gyúlnek, akik keresik a választ a globalizáció veszélyeire (Mcllvaine-Newsad, Merrett és McLaughlin, 2004), addig Kínában a CSA-k inkább a biztonságos élelmiszerforrást keresôket tömörítik (Gale, 2011; Shi, Cheng, Lei, Wen és Merrifield, 2011).

\section{Lokalitás: város-vidék tengely}

Közösségi mezôgazdálkodási formák jellemzôen nagyvárosok környezetében találhatók meg (Jarosz, 2008). A létrejövô gazda-fogyasztó kapcsolatok a gyakorlatban tehát növekvô interakciós lehetôséget és információáramlást biztosítanak a városlakók és a vidéken élók között, ami a CSA-tagság meghatározó momentuma (Dixon és Richards, 2016; Tegtmeier és Duffy, 2005). A városlakók szemében a vidéki régiók sokszor a szabad termelés otthonát jelentik, és olyan helyként vélekednek róluk, amit városi emberként nehezen érhetnének el. Ez az elérhetetlenségérzet csökkenthetô azáltal, hogy közvetlenül kapcsolódnak nemcsak a termelóhöz, vagyis a saját élelmiszerük elóállítójához (Cleveland, Copeland, Glasgow, McGinnis és Smith, 2016), hanem magához a gazdasághoz mint konkrét helyhez, és annak a földterületéhez (Cone és Myhre, 2000; Feagan és Henderson, 2009; Kis, 2014; Schnell, 2007).

\section{Személyes törődés}

A CSA-termelôk körülményeit elemzó kutatások az alternatív mezógazdálkodást mint életmódot vagy értékek kifejezôdését taglalják (Jarosz, 2011; Trauger és mtsai, 2010). E környezetben a közösséghez, élelmiszerhez, természethez, a földhöz, a vízhez való kapcsolódás fontos eleme a törôdés. A termelôk a gazdasági sikeresség és a termelékenység helyett sokszor a személyes odafigyelés és felelōsség, vagy etikai kérdések mentén múködtetik ökológiai gazdaságukat (Charles, 2011; Sumner, 2003; Wells és Gradwell, 2001). Nem véletlen, hogy a CSA-val kapcsolatos múködést a gon- 
doskodó törôdéssel, gondoskodó gyakorlattal (caring practice) társítja a szakirodalom (Charles, 2011; Jarosz, 2011; Trauger és mtsai, 2010; Wells és Gradwell, 2001).

Ez a fajta folyamatos jelenlét az élelmiszerhez társítottan természetesen a CSAtagokra is hatással van, a tagok a CSA-ban maguk is megélik a másokért (pl. család), vagy önmagukért való kiállás, gondoskodás örömét (DeLind és Ferguson, 1999). A gazda elérhetô közelsége, a saját élelmiszer-biztonság irányításának érzete, és az aktív környezettudatos múködés a bizalom, a kapcsolódás és a megbecsülés jelentôségét erôsítik bennük (Bougherara, Grolleau és Mzoughi, 2009; Cone és Kakaliouras, 1995; Cox és mtsai, 2008; Feagan és Henderson, 2009; Gale, 2011; Galt, 2013). A gyakorlatban a CSA-termelook jelentôs része nô (Wells és Gradwell, 2001), de a tagság nagy része is az: pl. Kane és Lohr (1997) az USA délkeleti részén lévô CSA-kat vizsgáló kutatásában 196 footoól választ kapva 84,6\%-os arányban említi a résztvevô nôi tagokat.

\section{Egészséges táplálkozás}

Az idesorolt irodalmakban jellemzô az összehasonlítás vagy követéses vizsgálódás, amelyet pl. a bevitt CSA-élelmiszer vs. nem kontrollált élelmiszer-bevitel között végeznek. A tagok nagy része a részvétel hozadékaként megnövekedett változatosságról számol be a zöldség- és gyümölcsfogyasztás, illetve az otthoni fớzés viszonylatában (Cohen és mtsai, 2012; MacMillan Uribe, Winham és Wharton, 2012; Minaker és mtsai, 2014). Ez köszönhetô annak, hogy a szigorúan idôzített heti szállítmányok vállalása erôsíti bennük az egészséges étkezés megvalósítását, és az étrendbeli kitartásuk javítását, az idetartozó attitûdváltozást és elkötelezôdést (Allen és mtsai, 2017; Cone és Kakaliouras, 1995; Tegtmeier és Duffy, 2005; Vasquez, Sherwood, Larson és Story, 2017). A részvétel következményeként csökkenhet a bolti bevásárlások száma, és ezzel együtt az egészségtelen ételek impulzusvásárlásának lehetôsége is (Hayden és Buck, 2012; Wharton, Hughner, MacMillan és Dumitrescu, 2015). Számos kutatás arról számol be, hogy a nyers ételek fogyasztása megnô, illetve sokkal több egészséges kísérô termék jelenik meg a tagok asztalán, mint például ecet, olívaolaj, fokhagyma (Sproul és Kropp, 2015; Wharton és mtsai, 2015). Fontos felvetés az is, hogy a CSA-részvétel a gyermekek számára egy alkalmas és elérhetô minta ahhoz, hogy szívesebben fogyasszanak egészséges ételeket (Birtalan, Pénzes, Rácz és Bárdos, 2018; Chen, 2013; Wharton és mtsai, 2015).

A tagok számára nem feltétlenül ismert, de népegészségügyi szempontból számos fontos eredmény is elérhetô mára a szakirodalomban. 151 fős, illetve 583 fôs vizsgálatok következtetéseit levonva látható, hogy noha a tagok nagy része a csatlakozáskor is tudatosan táplálkozik, a CSA-tagság eredményeként sokkal több zöldséget és gyümölcsöt esznek, mint amennyit maguktól, a tagság nélkül fogyasztanának (Cohen és mtsai, 2012; Wilkins, Farrell és Rangarajan, 2015). A megtermelt terményeket jellemzôen a betakarítás napján adja át a gazda, és ezért összehasonlításban a tagoknak magasabb az A-vitamin- és rostbevitelük, és több zöld színú zöldséget és sárga gyümölcsöt fogyasztanak az átlagos fogyasztókhoz képest (Cohen és mtsai, 2012; Forbes és Harmon, 2008; McCullum, 2004). Az elóbbieken túl a rendszeres zöldségfogyasztás eredményeként a szív- és érrendszeri megbetegedések vagy a túlsúly kockázatának csökkenése köthetô e fogyasztási modellhez (Aune és mtsai, 2017; Minaker és mtsai, 2014). 


\section{Életmódváltás}

\section{CSA-kötött életvitel}

Életviteli szempontból a kapott termények fơszerepbe kerülnek, az átvételtôl egészen a fogyasztásig (Kloppenburg és mtsai, 1996; Wharton és mtsai, 2015). Azáltal, hogy rendszeresen jutnak friss zöldséghez és gyümölcshöz a tagok, fokozatosan kialakul bennük egyfajta egészségtudatos magatartás, az étkezést elkezdik ennek egyik elsôdleges tényezőjéül tekinteni. Egy 274 fôs vizsgálat egyik következtetése, hogy a csatlakozás után jellemzôen megváltozik a tagok idóbeosztása, gondoljunk például az élelmiszer átvételével járó logisztikai kötelezettségekre vagy a sok nyers zöldség feldolgozására, elkészítésére (Perez, Allen és Brown, 2003). Mivel az otthoni fơzések gyakorisága is nô, így az étkezésekre fordított idô is nôni fog (Landis és mtsai, 2010), amit sokszor családi időtöltésként szerveznek meg a tagok, mintegy családi rituálékat létrehozva (Birtalan, Pénzes és mtsai, 2018; Birtalan, Rácz és Bárdos, 2018; Wharton és mtsai, 2015).

A CSA-tagok motivációs háttere változhat a részvétel során: bár fóként az egészségük feletti kontroll vonzza a CSA felé az érdeklődóket, ennek a szempontnak a jelentôsége csökkenhet a késôbbiekben, míg a szezonalitás és a hulladékcsökkentés (csomagolásmentesség) szerepe elôtérbe kerülhet (Cox és mtsai, 2008; Goland, 2002; Kis, 2014; O’Hara és Stagl, 2002). Tipikus CSA-tevékenységeknek számít az újrahasznosítás (pl. szövetszatyor használata, csomagolások kiváltása), a komposztálás és az otthoni étkezés (MacMillan Uribe és mtsai, 2012). A tagként eltöltött idô hosszának (pl. 5 év vs. 1 év tagság) hatása kimutatható: a régi tagok a részvételhez igazítják életvezetési szabályaikat, és inkább mellôzik a szupermarketbeli vásárlásokat (Cone és Myhre, 2000; Hayden és Buck, 2012).

\section{Életminôség}

Liu és munkatársai (Liu, Gilchrist, Taylor és Ravenscroft, 2017) e közegben olyan jótékony hatásokat is azonosítanak a kísérô folyamatok között (pl. a gazdaságban végzett önkéntes munka során tapasztalt belsố élmények; a természet körforgásával, földdel, gazdával történô kapcsolódásban megtapasztalt elemi meglátások), melyek akár a kilépés után is megmaradnak, és tartósak. Ahogy Delind idézi egy CSA-tagtól: „Ez egy csodálatos kihívás" (Goland, 2002). A résztvevốk e környezetben bizonyos vagányságot élhetnek meg (living dangerously), hisz olyasmiben tevékenykednek, amely a mindennapjaik során elérhetetlen lenne számukra (Ravenscroft és mtsai, 2013). A CSA-részvételhez kapcsolódó tevékenységek önkéntesen választott időtöltésként is értelmezhetôk, így a posztmodern szabadidő-kutatások megközelítéséból (pl. Blackshaw, 2010) a személyes rituális gyakorlatok kialakíthatósága, vagy a mélyebb személyes jelentôség megtalálása is kapcsolható ezen környezethez (Cone és Myhre, 2000; Kis, 2014; MacMillan Uribe és mtsai, 2012; Ravenscroft és mtsai, 2013; Wharton és mtsai, 2015).

A fentebb felsorolt változásokkal párhuzamosan a tagok számos érzelmet élnek meg a részvételük kapcsán: a büszkeségtôl kezdve az anticipáción át a bûntudatig (Wharton és mtsai, 2015). Az új termények megismerése, új ételek kitalálása, a helyi gazdaság 
fenntartásában betöltött szerep, a környezet védelme, a nosztalgia a CSA által kiváltott emlékek kapcsán (pl. gyerekkori vidéki emlékek), a termények kidobása, a CSA-ból való kilépés mind-mind okai lehetnek ezeknek. Chen (2013) a munkamegosztással múködô rendszerek (a tagok is bedolgoznak a földmunkákba) vizsgálata során ötféle érzelmi töltetet csoportosított a részvétellel kapcsolatban: boldogság, szabadság, életgazdagodás, stresszoldás és teljesítmény érzete. A fogyasztói kultúrában szokásos életmóddal szemben a CSA-részvétel a fenntarthatóságért, környezetért történô aktív, személyes felelôsségvállalást erôsíti (Fajzi és Erdei, 2015; Koger és Winter, 2011; MacMillan Uribe és mtsai, 2012). A kényelmi zónából való kilépés a tanulási zónába (Opitz, Specht, Piorr, Siebert és Zasada, 2017), a régi szokások lecserélése (vagyis az erôforrások aktivizálása) és az együttmúködés e közegben jelentôsen növelik az életminôséget, jóllétet (Galayda, 2006).

\section{Kényelmetlenségek}

Fontos tisztázni ugyanakkor, hogy a tagok kilépésének egyik fö oka az, hogy a CSA kapcsán számtalan, a kényelmes életmódot akadályozó tényezóvel (CSA inconveniences) találkoznak (Delind, 1999; Laird, 1998). A pszichológiai nehézségek, mint az új szokások kialakítása, alkalmazkodás a természethez, lemondás a „fogyasztói társadalomban" megszokott kényelemrôl, a részvétel ellenében hatnak. A tagok jellemzóen a szállítás, feldolgozás, elôkészítés és menütervezés hatásairól mondanak negatív véleményt (Cohen és mtsai, 2012; Goland, 2002; Lang, 2005; Ostrom, 1997; Vasquez és mtsai, 2017; White és mtsai, 2018). Az öndeterminációs elméletet alkalmazva Zepeda és munkatársai (Zepeda, Reznickova és Russell, 2013) azt találták, hogy a kiesés indoka lehet, hogy a részvétel nem támogatja autonómia-, kompetencia- és kapcsolódásszükségletüket, szemben a maradó tagokkal, akik megélik ezen szükségleteik kielégülését a CSA-ban. Úgy tûnik, hogy a fogyasztási szokásokhoz kapcsolódó megszokott elvárások aláássák a kezdeti lelkesedést, amit sokan nem tudnak, vagy nem kívánnak a mindennapokra lebontva megoldani (Delind, 1999).

\section{Újrairt sémák}

Az emberi gondolkodás jellegzetességeit, összegzô mintázatait jelöli a séma fogalma. A szakirodalom áttekintése alapján látható, hogy a CSA-ban mint élelmiszer-környezetben az élelmiszer, a szezonalitás, a természet, és a mezőgazdaság fogalmának személyes újrafogalmazására is sor kerülhet (Cox és mtsai, 2008; Feagan és Henderson, 2009; Hayden és Buck, 2012; Kloppenburg és mtsai, 1996; O’Hara és Stagl, 2002; Perez és mtsai, 2003; Schnell, 2013). Ilyen lehet a helyi (helyben termelés), a bio vagy ökológiai termelés (ebben a megközelítésben történô növénymegmunkálási megközelítés) korábban csak fogalomként ismert kifejezések gyakorlatban megélt megértése; avagy az élelmiszer fogalmának egy olyan láncolatba szervezódése, amelynek integráns része az egészséges termóföld, annak személyes kapcsolódása az étkezôvel, vagy a tiszta tápanyagon keresztüli figyelmes összekapcsoltság a környezettel. Ezen változásokat a tágabb társadalmi, gazdasági, ökológiai kontextus megtapasztalása vagy a fogyasztás 
új keretei ösztönzik (Ostrom, 1997; Rossi, 2017; Rossi, Allen, Woods és Davis, 2017; Rossi, Woods és Allen, 2017). E részvételi tapasztalat tehát tovább is gyúrúzhet: az az élmény, hogy a fogyasztói társadalom passzív tagjából az élelmiszerük elóállításának és elosztásának, valamint környezetüknek aktív alakítóivá válnak, hatással van arra, hogy a tagok másként gondolkozzanak, akár az életük más területein is változtassanak, ezáltal nagyobb kontrollt szerezzenek felette (Cox és mtsai, 2008; Kis, 2014). Kis (2014) pl. olyan személyes tapasztalást tár fel, ahol a CSA-zöldséghulladékból épített komposzt kapcsán a természeti életciklus - a környezet egészsége fogalmazódik újra, vagy Cox és kollégái (2008) a fogyasztói viselkedésben történô változásokat emelik ki: pl. hogyan változik meg az állatok élelmezésének fogalma.

\section{ÉRTÉKELÉS}

A CSA-részvétel alapvetôen egyszempontú megközelítéseit - ahogy Schnell (2013) megjegyzi, csak részterületeket elemeznek, atomizálják a tudományos taglalhatóságot - a szakirodalmak értelmezése és újszerú kategorizálása alapján egy többszempontú megközelítés-rendszerre alakítottuk át. Ezáltal a különbözó tudományterületek egymással nem kapcsolódó vizsgálódásait egy közös rendszerben is értelmezhetôvé tettük, integrálva a CSA-hoz való csatlakozás és a részvétel fenntartása mögött rejlô múködés magyarázó tényezôinek széles skáláját. Elemzésünk alapján a részvétel hat aspektusú komplex szerkezetét fogalmaztuk meg (1. ábra).

Ebben a megközelítési rendszerben a helyi egészséges élelmiszer-fogyasztást biztosító, személyességen, közvetlenségen és elkötelezôdésen alapuló CSA-részvétel benn-

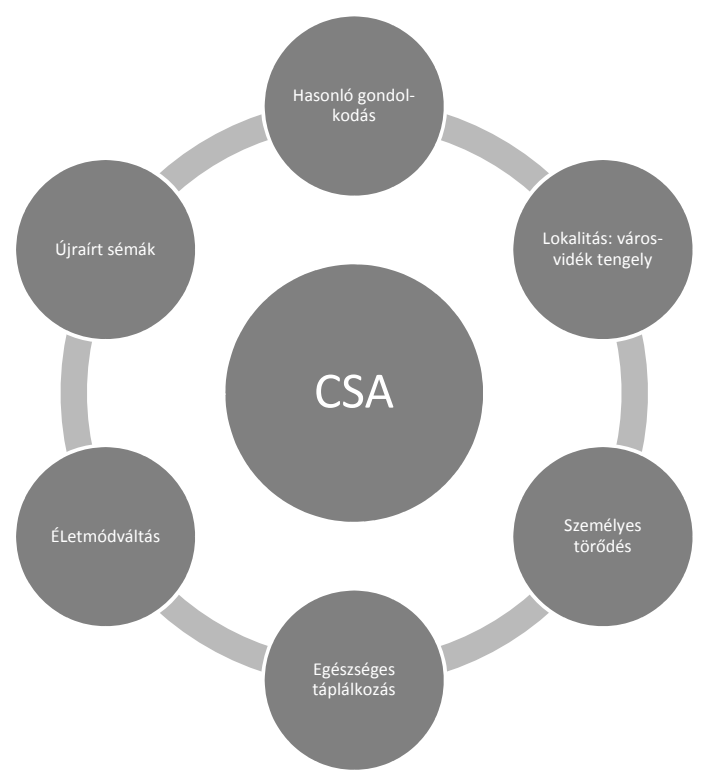

1. ábra. CSA-részvételi múködés hat aspektusa 
tartó aspektusainak hierarchiája, és azok sorrendjének változásai is kezelhetôk (vagyis kezelhetôvé válik, hogy egy adott keresztmetszeti vizsgálatban/részvétel hosszának függvényében melyik aspektus a legmeghatározóbb). Az olyan megállapítások, mint hogy egyesek számára a tagság a hetente megszerzett zöldséges dobozokkal kezdôdik és végzôdik (Cone és Kakaliouras, 1995), további jelentéstartalmakkal bôvülnek, hiszen pl. az Életmódváltás aspektus vagy az Újraírt sémák aspektus nem jelenik meg a redukált piaci értelmezésekben.

Egyre nagyobb jelentôséggel bír az egészséges életmódra nevelés, annak tudatosítása, hogy az egyének is felelôsek a saját és környezetük egészségéért (Bárdos és Kraiciné Szokoly, 2018). Az egészség fogalma a WHO (World Health Organization, 1948) megfogalmazása szerint a teljes testi, lelki és szociális jóllét állapota. E mára szúk értelmezésben áttekintésünk alapján a testi jóllétre közvetlenül az Egészséges táplálkozás, a lelki jóllétre a Személyes törôdés, a szociális jóllétre pedig a Hasonló gondolkodás hat (a többi aspektus esetében közvetett hatásokat fogalmazhatunk meg). Ugyanakkor az egészségfogalom az utóbbi évtizedekben jelentôs változáson ment keresztül - gondolunk itt a holisztikus egészségfelfogásra, illetve annak a környezeti és spirituális dimenziókkal való kibővülésére (ld. Benkô, 2005; Pálmai, 2017), amely már összes aspektusában közvetlenül is értelmezhetôvé teszi a CSA jelenségét (pl. Lokalitás, Újraírt sémák vagy Életmódváltás). A kiteljesedô egészség fogalma mellett a lelki egészség megközelítése is tisztult, és ezáltal tovább bôvült (Lippai, 2019): ez mára magába foglalja a személyben zajló szubjektív történések érzelmi harmóniáját, gondolati és spirituális összerendezettségét és realitását, így a feltárt Újraírt sémák, a Lokalitás és az Életmódváltás közvetlen hatása ezen keresztül is megfogalmazható.

A fentieket továbbgondolva és azt kiegészítve elmondható, hogy a CSA felé irányuló elkötelezôdés nemcsak az erőforrások aktivizálását és az együttmúködést jelenti: az amögött található érzelmi-gondolati beágyazottsága ennél összetettebb jelenség. A részvétel egyrészt hat a most általános fogyasztói szemléletmód és életvezetés negatív hatásainak csökkentésére, másrészt lehetôséget kínál az egyén számára az önmegvalósításra, önmagán túlmutató életcélok kialakítására (ld. Fajzi és Erdei, 2015), vagyis a fenntartható pozitív mentális egészség is vizsgálható általa.

\section{KÖVETKEZTETÉSEK}

A CSA-k közege komplex módon befolyásolhatja az egyéni részvételt, miközben makropolitikai szinten a WHO által ajánlott felelôs mezôgazdálkodás révén járul hozzá a táplálkozás és egészség szempontjainak összekapcsolhatóságához (Jones és Ejeta, 2015; Story, Kaphingst, Robinson-O’Brien és Glanz, 2008). A CSA-tagság interdiszciplinárisan nyitott, kvalitatív taglalása az élelmiszer, a fenntarthatóság, az egészség, és a mentális jóllét területén is releváns eredményeket hozhat, ezek kibontására további vizsgálódás szükséges.

Vélhetôen a rövid (kiesô) és a hosszú távú csatlakozás más-más típusú aspektusok mentén írható le jobban. Ezzel párhuzamosan felvetôdik a kérdés, hogy vajon mit nem találnak meg (mely aspektusban nem találnak fogódzót) azok, akik aztán kilépnek, és vajon mit visznek a kilépés ellenére magukkal (pl. Újraírt sémák). Tekintettel arra, 
hogy a fenntartható gondolkodásmód és viselkedés nagymértékben növeli a pozitív mentális egészséget és az ebból származó szubjektív jóllétet (Fajzi és Erdei, 2015), a részvétel pszichológiai megközelítése fontos lehet az élelmiszer-jóllét (food-wellbeing) fogalom multidiszciplináris továbbfejlesztésében (Ares és mtsai, 2016; Birtalan, Rigó és mtsai, 2018).

Mivel a CSA-ban való részvétel nem csupán fogyasztás, hanem életmódváltás is egyben, melynek hatása van a résztvevô egészségére, annak pszichológiai aspektusait is figyelembe kell venni. A fenntarthatóságért történô cselekvést, jóllétet, környezettudatosságot, egészségmagatartást, a közösségiséget vagy a testi-lelki-szociális-spirituális egészséget biztosíthatja az ökotudatos CSA-részvétel. Ugyanakkor a kényelmi zónából való kilépés nehézsége a fơ oka annak, hogy sok fogyasztó feladja az egészséges és fenntartható tevékenységeket. A szükségletek, motivációk, érzések és itt tapasztalt élmények pszichológiai vetületének elemzése segítségével ezeket a közösségeket még hatékonyabbá, stabilabbá és vonzóbbá lehetne tenni.

\section{KÖSZÖNETNYILVÁNÍTÁS}

Köszönettel tartozunk anonim lektorainknak, akik megjegyzéseikkel, mondanivalóikkal számos ponton segítették az anyag továbbfejlesztését.

\section{IRODALOM}

Adam, K. L. (2006). Community Supported Agriculture. Butte, MT: ATTRA-National Sustainable Agriculture Information Service.

Allen, J. E., Rossi, J., Woods, T. A., \& Davis, A. F. (2017). Do Community Supported Agriculture programmes encourage change to food lifestyle behaviours and health outcomes? New evidence from shareholders. International Journal of Agricultural Sustainability, 15(1), 70-82. https://doi.org/10.1080/14735903.2016.1177866

Ares, G., Giménez, A., Vidal, L., Zhou, Y., Krystallis, A., Tsalis, G., et al (2016). Do we all perceive food-related wellbeing in the same way? Results from an exploratory cross-cultural study. Food Quality and Preference, 52, 62-73. https://doi.org/10.1016/j.foodqual.2016.03.014

Aune, D., Giovannucci, E., Boffetta, P., Fadnes, L. T., Keum, N., Norat, T., et al (2017). Fruit and vegetable intake and the risk of cardiovascular disease, total cancer and all-cause mortality-a systematic review and dose-response meta-analysis of prospective studies. International Journal of Epidemiology, 46(3), 1029-1056. https://doi.org/10.1093/ije/dyw319

Bárdos, Gy., \& Kraiciné Szokoly, M. (2018). Egészség, életmód, egészségfejlesztés a felsôoktatás szemszögéból. Neveléstudomány, 2, 5-21.

Benkô, Zs. (2005). Bevezetés az egészségfejlesztésbe. In Benkô, Zs., \& Tarkó, K. (szerk.), Iskolai egészségfejlesztés. Szakmai és módszertani irások egészségterv készitéséhez (pp. 13-27.). Szeged:Juhász Gyula Felsôoktatási Kiadó.

Birtalan, I. L., Pénzes, M., Rácz, J., \& Bárdos, Gy. (2018). Szülôi fogyasztás - gyermeki tanulás. In Fehérvári, A., Széll, K. \& Misley, H. (szerk.), Kutatási sokszinúség, oktatási gyakorlat és együttmúködések - Absztrakt kötet - XVIII. Országos Neveléstudományi Konferencia (pp. 303.). Budapest, Magyarország: ELTE Pedagógiai és Pszichológiai Kar, MTA Pedagógiai Tudományos Bizottság. 
Birtalan, I. L., Rácz, J., \& Bárdos, Gy. (2018). AFN, as common business. In Pintér, G., Zsiborács, H., \& Csányi, S. (szerk.), Arccal vagy háttal a jövônek? - LX. Georgikon Napok, Abstract Volume (pp. 35.). Keszthely, Magyarország: Pannon Egyetem Georgikon Kar.

Birtalan, I. L., Rigó, A., Bárdos, Gy., Rácz, J., \& Oláh, A. (2018). Participation in Alternative Food Networks and Well-being. In Bognár, Cs., \& Móricz, K. (szerk.), 9st European Conference on Positive Psychology: Book of Abstracts (pp. 529.). Budapest, Magyarország: Akadémiai Kiadó AKCongress.

Blackshaw, T. (2010). Leisure. Abingdon: Routledge.

Bougherara, D., Grolleau, G., \& Mzoughi, N. (2009). Buy local, pollute less: What drives households to join a community supported farm? Ecological Economics, 68(5), 1488-1495. https:// doi.org/10.1016/j.ecolecon.2008.10.009

Brundtland, G. (1987). Our common future: Report of the 1987 World Commission on Environment and Development. United Nations (Sz. 1, 59.). Oslo: United Nations.

Charles, L. (2011). Animating community supported agriculture in North East England: Striving for a 'caring practice'. Journal of Rural Studies, 27(4), 362-371. https://doi.org/10.1016/j. jrurstud.2011.06.001

Chen, W. (2013). Perceived value of a community supported agriculture (CSA) working share. The construct and its dimensions. Appetite, 62, 37-49. https://doi.org/10.1016/j. appet.2012.11.014

Cleveland, D. A., Copeland, L., Glasgow, G., McGinnis, M. V., \& Smith, E. R. A. N. (2016). The Influence of Environmentalism on Attitudes Toward Local Agriculture and Urban Expansion. Society \& Natural Resources, 29(1), 88-103. https://doi.org/10.1080/08941920.2015.10 43081

Cohen, J. N., Gearhart, S., \& Garland, E. (2012). Community Supported Agriculture: A Commitment to a Healthier Diet. Journal of Hunger \& Environmental Nutrition, 7(1), 20-37. https:// doi.org/10.1080/19320248.2012.651393

Cone, C. A., \& Kakaliouras, A. (1995). Community supported agriculture: Building moral community or an alternative consumer choice. Culture, Agriculture, Food and Environment, 15(51-52), 28-31.

Cone, C. A., \& Myhre, A. (2000). Community-supported agriculture: A sustainable alternative to industrial agriculture? Human Organization, 59(2), 187-197. https://doi.org/10.17730/ humo.59.2.715203t206g2j153

Cooley, J. P., \& Lass, D. A. (1998). Consumer Benefits from Community Supported Agriculture Membership. Review of Agricultural Economics, 20(1), 227. https://doi.org/10.2307/1349547

Cox, R., Holloway, L., Venn, L., Dowler, L., Hein, J. R., Kneafsey, M., \& Tuomainen, H. (2008). Common ground? Motivations for participation in a community-supported agriculture scheme. Local Environment, 13(3), 203-218. https://doi.org/10.1080/13549830701669153

Cronin, J. J., Brady, M. K., \& Hult, G. T. M. (2000). Assessing the effects of quality, value, and customer satisfaction on consumer behavioral intentions in service environments. Journal of Retailing, 76(2), 193-218. https://doi.org/10.1016/S0022-4359(00)00028-2

DeLind, L. B. (2011). Are local food and the local food movement taking us where we want to go? Or are we hitching our wagons to the wrong stars? Agriculture and Human Values, 28(2), 273-283. https://doi.org/10.1007/s10460-010-9263-0

Delind, L. B. (1999). Close Encounters with a CSA: The Reflections of a Bruised and Somewhat Wiser Anthropologist. Agriculture and Human Values, 16, 3-9.

DeLind, L. B., \& Ferguson, A. (1999). Is This a Women's Movement? The Relationship of Gender to Community-Supported Agriculture in Michigan. Human Organization, 58(2), 190-200. https://doi.org/10.17730/humo.58.2.lpk17625008871x7 
Dixon, J., \& Richards, C. (2016). On food security and alternative food networks: Understanding and performing food security in the context of urban bias. Agriculture and Human Values, 33(1), 191-202. https://doi.org/10.1007/s10460-015-9630-y

Fajzi, Gy., \& Erdei, S. (2015). Fenntartható pozitív mentális egészség. A pozitív mentális egészség kibontakoztatása a fenntartható gondolkodásmód és viselkedés keretében. Mentálhigiéné és Pszichoszomatika, 16(1), 55-92.

Feagan, R., \& Henderson, A. (2009). Devon Acres CSA: Local struggles in a global food system. Agriculture and Human Values, 26(3), 203-217. https://doi.org/10.1007/s10460-008-9154-9

Forbes, C. B., \& Harmon, A. H. (2008). Buying into Community Supported Agriculture: Strategies for Overcoming Income Barriers. Journal of Hunger \& Environmental Nutrition, 2(2-3), 65-79. https://doi.org/10.1080/19320240801891479

Galayda, J. (2006). Community supported agriculture, economic preference theory and subjective well-being. New York: Doctoral dissertation. Rensselaer Polytechnic Institute.

Gale, H. F. (2011). Building trust in food. Letöltve: 2018. május 14-én: https://www.chinadialogue.net/article/4207-Building-trust-infood

Galt, R. E. (2013). The Moral Economy Is a Double-edged Sword: Explaining Farmers' Earnings and Self-exploitation in Community-Supported Agriculture: The Moral Economy Is a Double-edged Sword. Economic Geography, 89(4), 341-365. https://doi.org/10.1111/ ecge. 12015

Goland, C. (2002). Community supported agriculture, food consumption patterns, and member commitment. Culture, Agriculture, Food and Environment, 24(1), 14-25. https://doi. org/10.1525/cag.2002.24.1.14

Gulyás, E. (2011). Az etikus fogyasztás, mint a közügyekben való részvétel. PhD-értekezés. Budapest: Budapesti Corvinus Egyetem.

Hayden, J., \& Buck, D. (2012). Doing community supported agriculture: Tactile space, affect and effects of membership. Geoforum, 43(2), 332-341. https://doi.org/10.1016/j.geoforum. 2011.08.003

Jarosz, L. (2008). The city in the country: Growing alternative food networks in Metropolitan areas. Journal of Rural Studies, 24(3), 231-244. https://doi.org/10.1016/j.jrurstud.2007.10.002

Jarosz, L. (2011). Nourishing women: Toward a feminist political ecology of community supported agriculture in the United States. Gender, Place \& Culture, 18(3), 307-326. https://doi. org/10.1080/0966369X.2011.565871

Jones, A. D., \& Ejeta, G. (2015). A new global agenda for nutrition and health: The importance of agriculture and food systems. Bulletin of the World Health Organization, 94(3), 228-229. https://doi.org/10.2471/BLT.15.164509

Kane, D. J., \& Lohr, L. (1997). Maximizing shareholder retention in Southern CSAs. Portland: Organic Farming Research Foundation.

Kis, B. (2014). Community-supported agriculture from the perspective of health and leisure. Annals of Leisure Research, 17(3), 281-295. https:/ / doi.org/10.1080/11745398.2014.941885

Kis, B. (2017). Fenntartható fogyasztás és jóllét - A közösség által támogatott mezôgazdaság az egészség/ fejlesztés szemszögéból. Előadás, Személyes tér - közös világ; A Magyar Pszichológiai Társaság XXVI. Országos Tudományos Nagygyúlése, Szeged, Magyarország.

Kloppenburg, J., Hendrickson, J., \& Stevenson, G. W. (1996). Coming in to the foodshed. Agriculture and Human Values, 13(3), 33-42.

Koger, S. M., \& Winter, D. D. (2011). The Psychology of Environmental Problems: Psychology for Sustainability. Psychology Press.

Kotler, P. (2004). Marketing menedzsment. Budapest, Magyarország: KJK-Kerszöv.

Laird, T. (1998). Nonrenewal of membership and CSA inconvenience. CSA Farm Network, 2, 20-21. 
Lamb, G. (1994). Community Supported Agriculture/ Can it Become the Basis for a New Associative Economy? Elő́adás, 5th Community Supported Agriculture Conference, Kimberton, Pennsylvania.

Landis, B., Smith, T. E., Lairson, M., Mckay, K., Nelson, H., \& O’Briant, J. (2010). CommunitySupported Agriculture in the Research Triangle Region of North Carolina: Demographics and Effects of Membership on Household Food Supply and Diet. Journal of Hunger \& Environmental Nutrition, 5(1), 70-84. https://doi.org/10.1080/19320240903574403

Lang, K. B. (2005). Expanding Our Understanding of Community Supported Agriculture (CSA): An Examination of Member Satisfaction. Journal of Sustainable Agriculture, 26(2), 61-79. https://doi.org/10.1300/J064v26n02_06

Lang, K. B. (2010). The Changing Face of Community-Supported Agriculture. Culture \& Agriculture, 32(1), 17-26. https://doi.org/10.1111/j.1556-486X.2010.01032.x

Lippai, L. (2019). A boldogság jelentôsége a lelki egészség fejlesztésében. In Benkő, Zs., Lippai, L., \& Tarkó, K. (szerk.), Az egészség az életünk tartópillére (pp. 101-109.). Szeged: Szegedi Egyetemi Kiadó Juhász Gyula Felsôoktatási Kiadó.

Liu, P., Gilchrist, P., Taylor, B., \& Ravenscroft, N. (2017). The spaces and times of community farming. Agriculture and Human Values, 34(2), 363-375. https://doi.org/10.1007/ s10460-016-9717-0

MacMillan Uribe, A. L., Winham, D. M., \& Wharton, C. M. (2012). Community supported agriculture membership in Arizona. An exploratory study of food and sustainability behaviours. Appetite, 59(2), 431-436. https://doi.org/10.1016/j.appet.2012.06.002

McCullum, C. (2004). Using Sustainable Agriculture to Improve Human Nutrition and Health. Journal Community Nutrition, 6, 18-25.

Mcllvaine-Newsad, H., Merrett, C. D., \& McLaughlin, P. (2004). Direct from Farm to Table: Community Supported Agriculture in Western Illinois. Culture \& Agriculture, 26(1-2), 149-163. https://doi.org/10.1525/cag.2004.26.1-2.149

Minaker, L. M., Raine, K. D., Fisher, P., Thompson, M. E., Van Loon, J., \& Frank, L. D. (2014). Food Purchasing From Farmers' Markets and Community-Supported Agriculture Is Associated With Reduced Weight and Better Diets in a Population-Based Sample. Journal of Hunger \& Environmental Nutrition, 9(4), 485-497. https://doi.org/10.1080/19320248.2014.898175

O'Hara, S. U., \& Stagl, S. (2002). Endogenous preferences and sustainable development. The Journal of Socio-Economics, 31(5), 511-527.

Opitz, I., Specht, K., Piorr, A., Siebert, R., \& Zasada, I. (2017). Effects of consumer-producer interactions in alternative food networks on consumers' learning about food and agriculture. Moravian Geographical Reports, 25(3), 181-191. https://doi.org/10.1515/mgr-2017-0016

Ostrom, M. R. (1997). Toward a Community Supported Agriculture: A Case Study of Resistance and Change in the Modern Food System. Doctoral dissertation. Madison: University of Wisconsin.

Pálmai, J. (2017). A holisztikus egészségfogalom felé. In Lippai, L. (szerk.), Holisztikus egészség, egészségmagatartás és egészségfejlesztés (pp. 33-38.). Szeged: Szegedi Tudományegyetem.

Pascucci, S., Dentoni, D., Lombardi, A., Cembalo, L., 2016. Sharing values or sharing costs? Understanding consumer participation in alternative food networks. NJAS - Wageningen Journal of Life Sciences 78, 47 -60. https://doi.org/10.1016/j.njas.2016.03.006

Perez, J., Allen, P., \& Brown, M. (2003). Community supported agriculture on the central coast: The CSA member experience. UC Santa Cruz: Center for Agroecology and Sustainable Food Systems.

Pole, A., \& Gray, M. (2013). Farming alone? What's up with the "C" in community supported agriculture. Agriculture and Human Values, 30(1), 85-100. https://doi.org/10.1007/ s10460-012-9391-9 
Press, M., \& Arnould, E. J. (2011). Legitimating community supported agriculture through American pastoralist ideology. Journal of Consumer Culture, 11(2), 168-194. https://doi. org/10.1177/1469540511402450

Ravenscroft, N., Moore, N., Welch, E., \& Hanney, R. (2013). Beyond agriculture: The counter-hegemony of community farming. Agriculture and Human Values, 30(4), 629-639. https:/ / doi.org/10.1007/s10460-013-9437-7

Réthy, K., \& Dezsény, Z. (2013). Közösség által támogatott mezôgazdaság. Budapest: Ökológiai Mezôgazdasági Kutatóintézet.

Rossi, A. (2017). Beyond Food Provisioning: The Transformative Potential of Grassroots Innovation around Food. Agriculture, 7(1), 6. https://doi.org/10.3390/agriculture7010006

Rossi, J., Allen, J. E., Woods, T. A., \& Davis, A. F. (2017). CSA shareholder food lifestyle behaviors: A comparison across consumer groups. Agriculture and Human Values, 34(4), 855-869. https://doi.org/10.1007/s10460-017-9779-7

Rossi, J., Woods, T. A., \& Allen, J. (2017). Impacts of a Community Supported Agriculture (CSA) Voucher Program on Food Lifestyle Behaviors: Evidence from an Employer-Sponsored Pilot Program. Sustainability, 9(9), 1543. https://doi.org/10.3390/su9091543

Sabih, S. F., \& Baker, L. B. B. (1998). Alternative financing in agriculture: A case for the CSA method. Acta Horticulturae, 524, 141-148.

Schnell, S. M. (2007). Food with a Farmer's Face: Community-Supported Agriculture in the United States. Geographical Review, 97(4), 550-564. https://doi.org/10.1111/j.1931-0846.2007. tb00412.x

Schnell, S. M. (2013). Food miles, local eating, and community supported agriculture: Putting local food in its place. Agriculture and Human Values, 30(4), 615-628. https://doi. org/10.1007/s10460-013-9436-8

Shi, Y., Cheng, C., Lei, P., Wen, T., \& Merrifield, C. (2011). Safe food, green food, good food: Chinese Community Supported Agriculture and the rising middle class. International Journal of Agricultural Sustainability, 9(4), 551-558. https://doi.org/10.1080/14735903.2011.619327

Sproul, T. W., \& Kropp, J. D. (2015). A General Equilibrium Theory of Contracts in Community Supported Agriculture. American Journal of Agricultural Economics, 97(5), 1345-1359. https:/ / doi.org/10.1093/ajae/aav029

Story, M., Kaphingst, K. M., Robinson-O'Brien, R., \& Glanz, K. (2008). Creating Healthy Food and Eating Environments: Policy and Environmental Approaches. Annual Review of Public Health, 29(1), 253-272. https://doi.org/10.1146/annurev.publhealth.29.020907.090926

Sumner, J. (2003). Visions of sustainability: women organic farmers and rural development. Canadian Woman Studies, 23(1), 5.

Tegtmeier, E. M., \& Duffy, M. (2005). Community supported agriculture (CSA) in the Midwest United States: A regional characterization. Leopold Center Pubs and Papers, 151.

Thompson, C. J., \& Coskuner-Balli, G. (2007). Enchanting Ethical Consumerism: The case of Community Supported Agriculture. Journal of Consumer Culture, 7(3), 275-303. https://doi. org/10.1177/1469540507081631

Trauger, A., Sachs, C., Barbercheck, M., Brasier, K., \& Kiernan, N. E. (2010). "Our market is our community": Women farmers and civic agriculture in Pennsylvania, USA. Agriculture and Human Values, 27(1), 43-55. https://doi.org/10.1007/s10460-008-9190-5

Vasquez, A., Sherwood, N. E., Larson, N., \& Story, M. (2017). Community-Supported Agriculture as a Dietary and Health Improvement Strategy: A Narrative Review. Journal of the Academy of Nutrition and Dietetics, 117(1), 83-94. https://doi.org/10.1016/j.jand.2016.09.029

Wells, B. L., \& Gradwell, S. (2001). Gender and resource management: Community supported agriculture as caring-practice. Agriculture and Human Values, 18(1), 107-119. 
Wharton, C. M., Hughner, R. S., MacMillan, L., \& Dumitrescu, C. (2015). Community Supported Agriculture Programs: A Novel Venue for Theory-Based Health Behavior Change Interventions. Ecology of Food and Nutrition, 54(3), 280-301. https://doi.org/10.1080/03670 244.2014.1001980

White, M. J., Jilcott Pitts, S. B., McGuirt, J. T., Hanson, K. L., Morgan, E. H., Kolodinsky, J., et al (2018). The perceived influence of cost-offset community-supported agriculture on food access among low-income families. Public Health Nutrition, 21(15), 2866-2874. https://doi. org/10.1017/S1368980018001751

Wilkins, J. L., Farrell, T. J., \& Rangarajan, A. (2015). Linking vegetable preferences, health and local food systems through community-supported agriculture. Public Health Nutrition, 18(13), 2392-2401.

World Health Organization (1948). Preamble to the Constitution of the World Health Organization as adopted by the International Health Conference, New York, 19-22 June, 1946; signed on 22 July 1946 by the representatives of 61 States (Official Records of the World Health Organization, no. 2, p. 100) and entered into force on 7 April 1948. World Health Organization.

Zepeda, L., \& Leviten-Reid, C. (2004). Consumers' Views on Local Food. Journal of Food Distribution Research, 35(3), 1-6.

Zepeda, L., \& Li, J. (2006). Who buys local food? Journal of Food Distribution Research, 37(3), $1-11$.

Zepeda, L., Reznickova, A., \& Russell, W. S. (2013). CSA membership and psychological needs fulfillment: An application of self-determination theory. Agriculture and Human Values, 30(4), 605-614. https://doi.org/10.1007/s10460-013-9432-z

Zsolnai, L., \& Podmaniczky, L. (2010). Community Supported Agriculture. In Tencati, A. \& Zsolnai, L. (Eds), The Collaborative Enterprise: Creating Values for a Sustainable World (pp. 137-150.). Oxford: Peter Lang Academic Publishers.

\section{NYILATKOZAT ÉRDEKÜTKÖZÉSRŐL}

A szerzôk ezúton kijelentik, hogy esetükben nem állnak fenn érdekütközések.

A cikk a Creative Commons Attribution 4.0 International License (https://creativecommons. org/licenses/by/4.0) feltételei szerint publikált Open Access közlemény, melynek szellemében a cikk bármilyen médiumban szabadon felhasználható, megosztható és újraközölhetô, feltéve, hogy az eredeti szerzô és a közlés helye, illetve a CC License linkje és az esetlegesen végrehajtott módosítások feltüntetésre kerülnek. (SID_1) 


\section{SUBJECTIVE ASPECTS OF COMMUNITY SUPPORTED AGRICULTURE}

\section{BIRTALAN, ILONA LILIÁNA - KIS, BERNADETT - BÁRDOS, GYÖRGY}

Theoretical background: Community Supported Agriculture (CSA) is a rapidly growing phenomenon worldwide, a model of production and distribution of local food that connects the producer and consumers (members) directly. As a grassroot initiative, CSAs can be seen as a step towards the decommodification of food and are directly associated with sustainability which is rarely involved in psychological and health promotional discourse in Hungary.

Methods: In the selection process of literature, at first papers containing specific word combinations were selected. Articles recommended by academic literature search portals during this process and references section of the selected papers were studied further in the context CSA involvement to find more relevant articles.

Results: Based on our review it seems that CSA participation can be interpreted not only through factual advantages: Similar Thinking, Locality: urban-rural axis, Personal Care, Lifestyle Change, and Rewriting of Schemes are at least as important.

Consequencies: According to our view, studying participation in CSA may yield useful information for developing the concept of sustainable positive mental health.

Keywords: Community Supported Agriculture; CSA participation (membership); consumption; lifestyle; mental health 